\title{
Spatial variation of epoxyscillirosidine concentrations in Moraea pallida (yellow tulp) in South Africa
}

\author{
Authors: \\ Christo J. Botha \\ Heleen Coetser ${ }^{2}$ \\ Rowena A. Schultz ${ }^{2}$ \\ Leonie Labuschagne ${ }^{2}$ \\ Deon van der Merwe

\section{Affiliations:} \\ ${ }^{1}$ Department of Paraclinical \\ Sciences, University of \\ Pretoria, South Africa \\ ${ }^{2}$ Division of Toxicology, \\ Agricultural Research \\ Council-Onderstepoort \\ Veterinary Institute, \\ South Africa \\ ${ }^{3}$ Department of Diagnostic \\ Medicine/Pathobiology, \\ Kansas State Veterinary \\ Diagnostic Laboratory, \\ Kansas State University, \\ United States
}

Correspondence to: Christo Botha

Email:

christo.botha@up.ac.za

Postal address:

Private Bag X04,

Onderstepoort 0110,

South Africa

Dates:

Received: 05 Dec. 2012

Accepted: 26 Apr. 2013

Published: 31 May 2013

How to cite this article: Botha, C.J., Coetser, H., Schultz, R.A., Labuschagne, L. \& Van der Merwe, D., 2013, 'Spatial variation of epoxyscillirosidine concentrations in Moraea pallida (yellow tulp) in South Africa', Onderstepoort Journal of Veterinary Research 80(1), Art. \#543, 6 pages. http://dx.doi. org/10.4102/ojvr.v80i1.543

\section{Copyright:}

(C) 2013. The Authors. Licensee: AOSIS OpenJournals. This work is licensed under the Creative Commons Attribution License.

Read online:
Moraea pallida (yellow tulp) poisoning is economically the most important intoxication of livestock in South Africa. Poisoning varies according to locality, climatic conditions and growth stage of the plant. The primary objective of this study was to determine the concentration of the toxic principle, epoxyscillirosidine, in yellow tulp leaves and to ascertain the variability of epoxyscillirosidine concentrations within and between different locations. A secondary objective was to utilise Geographic Information Systems in an attempt to explain the variability in toxicity. Flowering yellow tulp plants were collected at 26 sampling points across 20 districts of South Africa. The leaves of five plants per sampling point were extracted and submitted for liquid chromatography/mass spectrometry analysis. A large variation in mean epoxyscillirosidine concentrations, ranging from $3.32 \mu \mathrm{g} / \mathrm{g}-238.27 \mu \mathrm{g} / \mathrm{g}$, occurred between different geographical regions. The epoxyscillirosidine concentrations also varied tremendously between individual plants $(n=5)$ collected at the same sampling point, with up to a 24 times difference between the lowest and highest concentration detected. No generalised correlation between epoxyscillirosidine concentrations and soil elemental concentrations could be established. However, samples obtained from the north-eastern part of the sampling region tended to have higher epoxyscillirosidine concentrations compared to samples obtained from the south-western part of the sampling region. Higher toxin concentrations in the northeast were associated with statistically significant higher soil concentrations of iron, bismuth, bromide, cadmium, chromium, rubidium, tellurium, thallium, titanium and zinc, whilst soil concentrations of strontium and soil $\mathrm{pH}$, were significantly lower. This study corroborated the contention that epoxyscillirosidine concentration in yellow tulp fluctuates and may explain the variability in toxicity.

\section{Introduction}

Poisoning of livestock by cardiac glycoside-containing plants has the greatest economic impact of all plant-associated poisonings in the Republic of South Africa. Collectively, they are held responsible for $33 \%$ of all mortalities from plant poisonings of cattle and $10 \%$ of those in small stock (Kellerman, Naudé \& Fourie 1996).

Chemically, two major groups of cardiac glycosides, namely the cardenolides and bufadienolides, are recognised (Steyn \& Van Heerden 1998). Poisoning of livestock by bufadienolide-containing plants, which surpasses cardenolide-induced poisonings in importance, may either be acute or chronic. Tulp poisoning (induced by various Moraea species) and slangkop poisoning (caused by various Drimia species) induce only acute intoxication, as these species contain non-cumulative bufadienolides (Kellerman et al. 2005). On the other hand, members of three genera of the Crassulaceae (Cotyledon, Tylecodon and Kalanchoe), generally referred to as plakkies, may cause either acute or chronic poisoning as they contain cumulative, neurotoxic bufadienolides. The chronic form of the poisoning is colloquially referred to as krimpsiekte (Botha 2003).

Tulp poisoning is the most important plant-associated poisoning in South Africa and occurs throughout the country. It is predominantly found in newly-introduced cattle or young, naive animals (Kellerman, Naudé \& Fourie 1996; Kellerman et al. 2005). Moraea pallida (yellow tulp) contains a bufadienolide, namely $1 \alpha, 2 \alpha$-epoxyscillirosidine and is predominantly responsible for the intoxication of livestock (Enslin et al. 1966; Kellerman et al. 2005). However, yellow tulp poisoning is reported to vary according to locality, climatic conditions and growth stage (Kellerman et al. 2005). Thus, it is assumed that the epoxyscillirosidine concentration in yellow tulp varies between different geographic regions of the country. In a limited study, Snyman, Schultz \& Van den Berg (2011) linked cardiac glycoside content to values obtained with an immunoassay (digoxin equivalents) and reported variability in yellow tulp toxicity.

The first objective of this study was to determine epoxyscillirosidine concentration in yellow tulp leaves collected at different geographical regions in South Africa. The second objective of this study was to utilise a geographic information system (GIS) to establish if the differences 
over geographic regions (assuming that the difference is not genetically driven), were due to variations in edaphic parameters that could influence the synthesis and accumulation of epoxyscillirosidine in the plant.

\section{Materials and methods Plant material}

Moraea pallida was collected in different geographical regions of South Africa during September 2010 - October 2010. Ten to 15 plants, growing in close proximity to each other (within approximately $1 \mathrm{~m}^{2}$ ) in grazing camps, were collected per sampling point by digging up the plants. At each site, global positioning system (GPS) sampling point locations were recorded in terms of longitude and latitude using handheld GPS sensors and the WGS 84 map datum. A voucher specimen from each site was retained, pressed and mounted on cardboard. The HGW Schweickertd Herbarium, at the University of Pretoria, verified the botanical identification. The voucher specimens were kept at the Toxicology Biolab, Agricultural Research CouncilOnderstepoort Veterinary Institute (ARC-OVI). The remaining plants were dried in an oven (Protea Laboratory Equipment) at $60{ }^{\circ} \mathrm{C}$ until the mass stabilised. From the batch of plants collected per sampling point, the five plants with the best leaves (longest and broadest) were selected for extraction.

\section{Epoxyscillirosidine concentration}

The leaves of the five plants per sampling point were extracted separately. The extraction procedures followed the standardised method used at the Toxicology Laboratory, ARC-OVI (Schultz, Kellerman \& Van den Berg 2005). Briefly, the dried leaves were finely milled; $0.5 \mathrm{~g}$ dry plant material was homogenised for five minutes in dichloromethane $(80 \mathrm{~mL}$, British Drug House [BDH], England) and deionised water $(40 \mathrm{~mL})$ to which ten drops of concentrated hydrochloric acid (Merck, South Africa) were added. The sample was shaken for 30 minutes and then centrifuged $(2400 \mathrm{x}$ g) for 30 minutes. The precipitate was removed with a pipette and placed in a clean flask; $40 \mathrm{~mL}$ of deionised water with 20 drops ammonia (Merck, South Africa) was added, shaken for 30 minutes and then centrifuged for 30 minutes. The bottom layer was filtered through sodium sulphate (approximately $20 \mathrm{~g}$ ) on a Whatman 1 filter paper to remove moisture. The filtrate was evaporated to dryness $\left(<50{ }^{\circ} \mathrm{C}\right)$, after which $2 \mathrm{~mL}$ analytical grade methanol (Merck, South Africa) was added (dissolved in an ultrasonic bath) and filtered ( $0.45 \mu$ Nylon filter).

The extracts were submitted to the Laboratory of The National Horse Racing Authority, Johannesburg to determine the epoxyscillirosidine concentrations. The samples were dried at room temperature, reconstituted in $2 \mathrm{~mL}$ methanol (Merck, South Africa) and vortex mixed for 30 seconds. The samples were then diluted by transferring $100 \mu \mathrm{l}$ of each sample to a high performance liquid chromatography (HPLC) vial and methanol $900 \mu \mathrm{l}$ and $100 \mu \mathrm{l}$ of internal standard (proscillaridin A, Sigma-Aldrich, Germany) in methanol $(10 \mu \mathrm{g} / \mathrm{mL})$ were added. Samples were submitted for liquid chromatography/ mass spectrometry (LC-MS). An Agilent 1260 Series Liquid Chromatograph (Agilent Technologies, South Africa) was employed with a Waters XSelect CSH C $18150 \mathrm{~mm} \times 2.1 \mathrm{~mm}$ column $(5 \mu \mathrm{m}$ particle size). The mobile phase was $5 \mathrm{mM}$ ammonium acetate and $0.1 \%$ formic acid in water:acetonitrile $(98 / 2, \mathrm{v} / \mathrm{v})$ (Solvent A) and $5 \mathrm{mM}$ ammonium acetate and $0.1 \%$ formic acid in water: acetonitrile, $(2 / 98, \mathrm{v} / \mathrm{v})$ (Solvent B). The liquid chromatograph was interfaced to a Thermo Scientific Exactive high-resolution mass spectrometer (Thermo Scientific, South Africa) equipped with a HeatedElectrospray lonisation probe (HESI-II), utilising Xcalibur software version 2.1 with ToxID 2.1.2.

\section{Soil}

Sub-soil samples (one $500 \mathrm{~g}$ per sampling point) were collected from the root zone of the plants following removal of the top $3 \mathrm{~cm}-5 \mathrm{~cm}$ of soil. The soil samples were submitted to the ARC-Institute for Soil, Climate and Water (ARC-ISCW), Pretoria for analyses of $\mathrm{K}, \mathrm{Ca}, \mathrm{Mg}, \mathrm{Na}, \mathrm{pH}\left(\mathrm{H}_{2} \mathrm{O}\right)$, phosphate and resistance. An inductively coupled plasma/mass spectrometry (ICP-MS) scan on an ammonium EDTA extract of the samples, including analyses of $\mathrm{Li}, \mathrm{Be}, \mathrm{B}, \mathrm{Ti}, \mathrm{V}, \mathrm{Cr}, \mathrm{Mn}$, $\mathrm{Co}, \mathrm{Ni}, \mathrm{Cu}, \mathrm{Zn}, \mathrm{As}, \mathrm{Br}$, Se, Rb, Sr, Mo, Cd, Sn, Sb, Te, I, Cs, $\mathrm{Ba}, \mathrm{La}, \mathrm{W}, \mathrm{Pt}, \mathrm{Hg}, \mathrm{Tl}, \mathrm{Pb}$, and $\mathrm{U}$ was performed. Correlations between soil elements and median epoxyscillirosidine concentrations were investigated using the Pearson product moment correlation method (SigmaPlot for Windows version 11.0; build 11.2.0.5). Statistical significance was assumed at a confidence level of $95 \%$ and above.

\section{GIS spatial analysis}

Spatial distributions of yellow tulp epoxyscillirosidine concentrations were studied in a GIS environment (ESRI 2008: ArcMap 10.0; build 2414). The median epoxyscillirosidine concentration for each site was compiled and the data were projected into the Africa-Albers equal area conic coordinate system. To determine whether the data distribution was spatially autocorrelated or not, a spatial autocorrelation analysis was performed by calculating the global Moran's I-statistic using inverse distance conceptualisation and Euclidian distance. To determine whether the data displayed spatial high-low trends, a highlow clustering analysis was performed by calculating a general G-statistic using inverse distance conceptualisation and Euclidian distance.

\section{Comparative statistical analysis}

Visual inspection of the data revealed an apparent, strong difference in epoxyscillirosidine concentrations along a southwest (SW) to north-east (NE) distribution axis. To describe the difference statistically, the data was divided into two groups, NE and SW, based on a dividing line stretching from $-26^{\circ} \mathrm{N}, 24^{\circ} \mathrm{E}$ to $-30^{\circ} \mathrm{N}, 29^{\circ} \mathrm{E}$. The two groups were compared using a $t$-test when the data were normal, and had equal variance; otherwise the two groups were compared using the Mann-Whitney rank sum test. A significant difference between groups was assumed when the difference reached a 95\% confidence level $(p<0.050)$.

\section{Results}

Flowering $M$. pallida were collected at 26 sampling points across 20 districts of South Africa (Figure 1). The mean and 
median epoxyscillirosidine concentrations, as well as the lowest and highest concentrations in the yellow tulp leaves $(n=5)$ collected at each sampling point, are tabled (Table 1). The data is not normally distributed.

A large variation in mean epoxyscillirosidine concentrations was noticed between geographical regions, ranging from $3.32( \pm 0.56) \mu \mathrm{g} / \mathrm{g}$ at Excelsior to $238.27( \pm 232.21) \mu \mathrm{g} / \mathrm{g}$ at Frankfort. Huge differences in epoxyscillirosidine concentrations between individual plants within a plant community were also detected at certain sampling points. The largest variations in individual epoxyscillirosidine concentrations in plants growing in close proximity to each other were recorded at Bloemhof, Rouxville and Bethlehem, with a 24, 20 and 18 times difference between the lowest and highest concentrations respectively.

The spatial autocorrelation analysis resulted in a Moran's index $I$-statistic of 0.649 , a $z$-score of 0.878 , with a $p$-value of 0.380 . The spatial distribution of epoxyscillirosidine concentration therefore appeared not to be significantly different from random, but the power of the analysis was poor due to a low sample number. The overall highlow clustering analysis resulted in a general G-statistic of 0.000024 , a $z$-score of -0.287 , and a $p$-value of 0.774 , indicating that the overall spatial distribution of high and low values was not significantly different from random. However, there was a statistically significant difference $(p<0.001)$ in median epoxyscillirosidine concentrations of plants to the SW and NE of a diagonal divisional line drawn from NW to SE, based on a dividing line stretching from $-26^{\circ} \mathrm{N}, 24^{\circ} \mathrm{E}$ to $-30^{\circ} \mathrm{N}, 29^{\circ} \mathrm{E}$, with median concentrations of $5 \mu \mathrm{g} / \mathrm{g}$ and $54 \mu \mathrm{g} / \mathrm{g}$ respectively (Figure 1). This sample division also resulted in significant soil differences. Significantly higher toxin concentration in the NE was associated with higher soil concentrations of $\mathrm{Fe}, \mathrm{Bi}, \mathrm{Br}, \mathrm{Cd}$, $\mathrm{Cr}, \mathrm{Rb}, \mathrm{Te}, \mathrm{Tl}, \mathrm{Ti}$ and $\mathrm{Zn}$, whilst soil concentrations of $\mathrm{Sr}$ and soil $\mathrm{pH}$ were significantly lower (Table 2).

\section{Discussion}

This study corroborates the notion that the toxicity of yellow tulp is highly variable and confirms a previous report of relatively low cardiac glycoside content (reflected as digoxin equivalents) in yellow tulp collected at Griekwastad and Bloemfontein (Snyman, Schultz \& Van den Berg 2011). In the current study, yellow tulp leaves collected at Belfast, Mpumalanga Highveld had a high mean epoxyscillirosidine

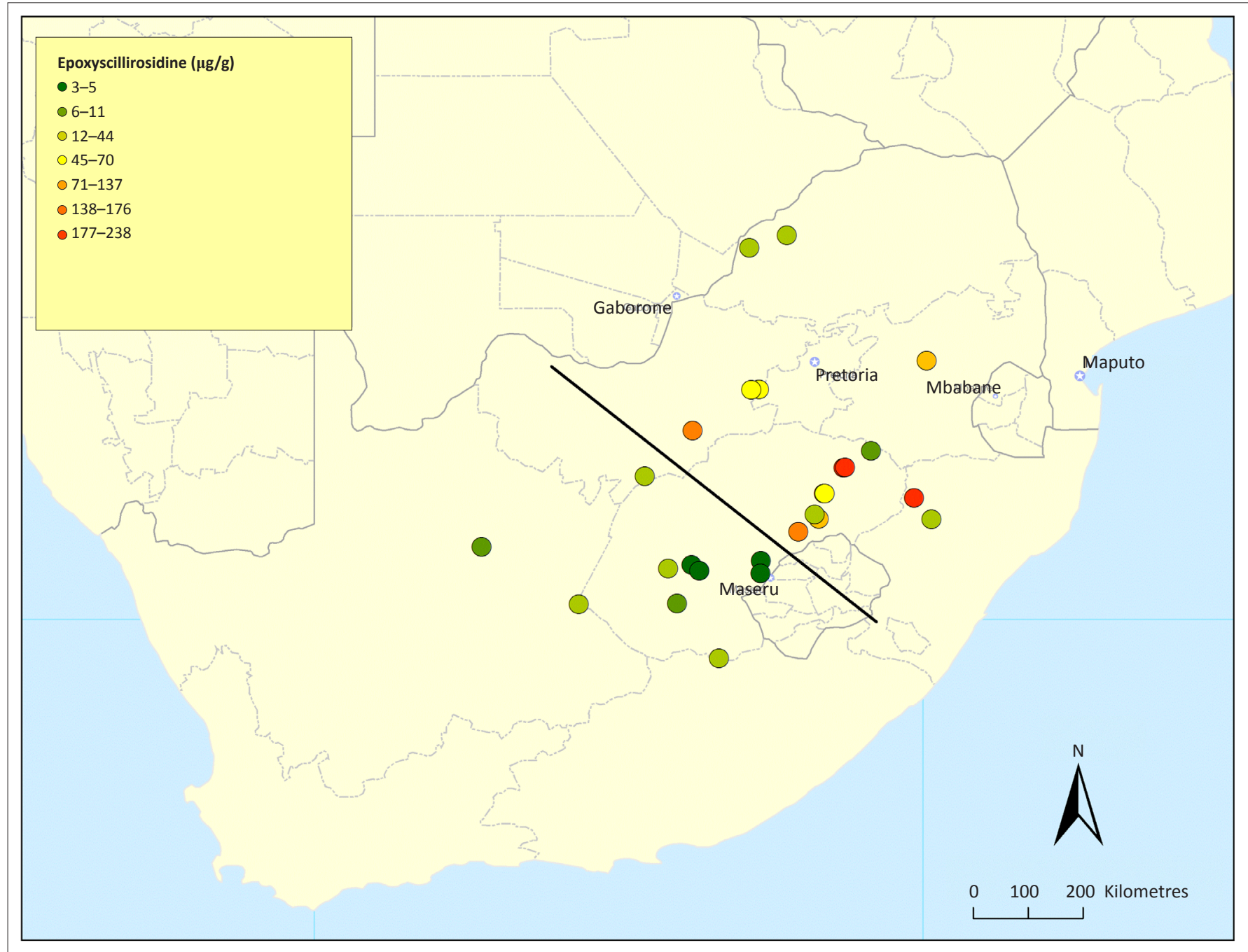

FIGURE 1: Mean epoxyscillirosidine concentrations of flowering Moraea pallida leaves $(n=5)$ collected at 26 locations in South Africa to the north-east and south-west of a diagonal divisional line drawn between $-26^{\circ} \mathrm{N}, 24^{\circ} \mathrm{E}$ to $-30^{\circ} \mathrm{N}, 29^{\circ} \mathrm{E}$. 
TABLE 1: Epoxyscillirosidine concentrations in flowering Moraea pallida leaves $(n=5)$ and variability per sampling point of plants collected during September - October 2010 at various geographical regions of South Africa.

\begin{tabular}{|c|c|c|c|c|c|c|c|}
\hline District/Province & Coordinates & $\begin{array}{l}\text { Mean } \\
(\mu \mathrm{g} / \mathrm{g})\end{array}$ & $\begin{array}{l}\text { Standard } \\
\text { deviation }\end{array}$ & $\begin{array}{l}\text { Median } \\
(\mu \mathrm{g} / \mathrm{g})\end{array}$ & $\begin{array}{l}\text { Minimum } \\
(\mu \mathrm{g} / \mathrm{g})\end{array}$ & $\begin{array}{l}\text { Maximum } \\
(\mu \mathrm{g} / \mathrm{g})\end{array}$ & $\begin{array}{l}\text { Magnitude of } \\
\text { difference }(x)\end{array}$ \\
\hline De Brug; Free State & $\mathrm{S} 29^{\circ} 09.040 \mathrm{E} 025^{\circ} 48.230$ & 28.19 & 18.38 & 24.03 & 10.02 & 51.06 & 5.10 \\
\hline Normandien, Newcastle; KwaZulu-Natal & $\mathrm{S} 27^{\circ} 58^{\prime}$ E $29^{\circ} 48^{\prime}$ & 227.61 & 114.07 & 207.64 & 114.08 & 418.06 & 3.70 \\
\hline Ladybrand; Free State & $\mathrm{S} 29^{\circ} 01.854$ E $27^{\circ} 06.921$ & 3.84 & 0.75 & 3.71 & 3.16 & 5.10 & 1.60 \\
\hline Vrede; Free State & S $27^{\circ} 19377367$ E $29^{\circ} 1438$ & 9.47 & 12.49 & 3.74 & 2.82 & 31.70 & 11.20 \\
\hline Hopetown; Northern Cape & S 29.8121 E 24.4050 & 29.68 & 17.22 & 29.9 & 8.40 & 50.55 & 6.00 \\
\hline Ventersdorp; North-West & S $26^{\circ} 07^{\prime} 262^{\prime \prime}$ E $27^{\circ} 09^{\prime} 552^{\prime \prime}$ & 67.22 & 33.26 & 53.92 & 35.28 & 119.40 & 3.40 \\
\hline Ventersdorp; North-West & S $26^{\circ} 10^{\prime} 25.5^{\prime \prime}$ E $27^{\circ} 10^{\prime} 25.4^{\prime \prime}$ & 52.71 & 35.44 & 34.65 & 26.90 & 113.55 & 4.20 \\
\hline Hartbeesfontein; North-West & S $26^{\circ} 51^{\prime} 17.4^{\prime \prime}$ E $26^{\circ} 12^{\prime} 49.2^{\prime \prime}$ & 162.26 & 94.11 & 105.23 & 96.35 & 312.64 & 3.20 \\
\hline Bloemfontein; Free State & $\mathrm{S} 29^{\circ} 05^{\prime} 10^{\prime \prime}$ E $26^{\circ} 12^{\prime} 3^{\prime \prime}$ & 4.00 & 1.18 & 3.54 & 2.96 & 5.99 & 2.00 \\
\hline Bloemfontein; Free State & $\mathrm{S} 29^{\circ} 11^{\prime} 16^{\prime \prime}$ E $26^{\circ} 19^{\prime} 3^{\prime \prime}$ & 4.25 & 1.28 & 4.51 & 2.88 & 5.85 & 2.00 \\
\hline Bloemfontein; Free State & S 29 11'16" E 26 19'6" & 5.13 & 2.72 & 4.05 & 3.40 & 9.95 & 2.90 \\
\hline Lephalale (Ellisras); Limpopo & S $23^{\circ} 36^{\prime} 20.1^{\prime \prime}$ E $27^{\circ} 44^{\prime} 50.1^{\prime \prime}$ & 44.03 & 29.19 & 37.400 & 10.15 & 87.17 & 8.60 \\
\hline Roosendal; Free State & $\mathrm{S} 28^{\circ} 32^{\prime} 32^{\prime \prime}$ E $27^{\circ} 56^{\prime} 32^{\prime \prime}$ & 160.80 & 120.33 & 95.01 & 63.61 & 328.19 & 5.16 \\
\hline Frankfort; Free State & S $27^{\circ} 4568$ E $28^{\circ} 6926^{\prime}$ & 238.27 & 232.21 & 163.41 & 47.44 & 640.19 & 13.50 \\
\hline Frankfort; Free State & $\mathrm{S} 27^{\circ} 455 \mathrm{E} 28^{\circ} 72$ & 215.46 & 71.25 & 225.89 & 127.68 & 317.51 & 2.50 \\
\hline Reitz; Free State & $\mathrm{S} 27^{\circ} 90913 \mathrm{E} 028^{\circ} 36163$ & 175.72 & 188.26 & 72.34 & 26.33 & 434.07 & 16.50 \\
\hline Reitz; Free State & $\mathrm{S} 27^{\circ} 91092 \mathrm{E} 028^{\circ} 36311$ & 69.63 & 40.75 & 50.03 & 27.08 & 125.62 & 4.60 \\
\hline Bethlehem; Free State & $\mathrm{S} 28^{\circ} 26135 \mathrm{E} 028^{\circ} 21433$ & 26.76 & 41.97 & 8.42 & 5.54 & 101.78 & 18.37 \\
\hline Edenburg; Free State & S $29^{\circ} 43^{\prime} 57.7^{\prime \prime}$ E $25^{\circ} 57^{\prime} 34.6^{\prime \prime}$ & 10.78 & 8.79 & 6.85 & 3.86 & 24.38 & 6.30 \\
\hline Lephalale (Ellisras); Limpopo & $\mathrm{S} 23^{\circ} 49^{\prime} 32.6^{\prime \prime}$ E $27^{\circ} 08^{\prime} 03.1^{\prime \prime}$ & 19.75 & 27.14 & 7.66 & 5.70 & 68.20 & 12.00 \\
\hline Excelsior; Free State & S $28^{\circ} 56^{\prime} 334^{\prime \prime}$ E $027^{\circ} 07^{\prime} 807^{\prime \prime}$ & 3.32 & 0.56 & 3.15 & 2.85 & 4.18 & 1.50 \\
\hline Rouxville; Free State & $\mathrm{S} 30^{\circ} 36^{\prime} 72^{\prime \prime}$ E $26^{\circ} 37^{\prime} 92^{\prime \prime}$ & 25.50 & 28.86 & 5.27 & 2.90 & 59.20 & 20.40 \\
\hline Belfast; Mpumalanga & S $25^{\circ} 37^{\prime} 59.01$ E $295^{\prime} 48.78$ & 136.95 & 104.94 & 80.53 & 59.53 & 307.63 & 5.20 \\
\hline
\end{tabular}

$*, n=4$, one sample was not analysed; $\mu \mathrm{g} / \mathrm{g}$, micrograms per gram; $x$, times difference.

concentration of $136.95( \pm 104.94) \mu \mathrm{g} / \mathrm{g}$. Snyman et al. (2011) also reported relatively high cardiac glycoside content (18 438 nmoles/L) in a plant (only one sample) collected at Middelburg on the Mpumalanga Highveld. However, it is difficult to compare as Snyman et al. (2011) utilised an indirect analysis (digoxin assay) to estimate the cardiac glycoside content.

The differences in epoxyscillirosidine concentration in yellow tulp can explain the variability in toxicity. However, poisoning will depend on the amount of plant material ingested and even though the epoxyscillirosidine concentration in the plant material may be low, if sufficient plant material is ingested it can induce intoxication. This is well illustrated as plant material collected during incidences of tulp poisoning near Newcastle and Glencoe (Annema, private practitioner, personal communication) was found to be quite diverse. The mean epoxyscillirosidine concentration in yellow tulp leaves $(n=5)$ at Newcastle was high at $227.61( \pm 114.07) \mu \mathrm{g} / \mathrm{g}$ and relatively low at Glencoe at $23.05( \pm 15.49) \mu \mathrm{g} / \mathrm{g}$. In conditioned feed aversion trials, Snyman et al. (2004) reported that the lowest oral dose of epoxyscillirosidine that induces clinical signs of poisoning in cattle is $0.10 \mathrm{mg} / \mathrm{kg}$ body weight. Based on the mean epoxyscillirosidine concentrations found at Newcastle and Glencoe, it is estimated that a young steer of $300 \mathrm{~kg}$ has to ingest $130 \mathrm{~g}-1300 \mathrm{~g}$ of dry plant material or $0.43 \mathrm{~g}-4.30 \mathrm{~g}$ of dry plant material per kilogram body weight. These estimated toxic doses for cattle are comparable to lethal oral doses of $1.25 \mathrm{~g} / \mathrm{kg}$ of dried, milled Moraea pallida plant material administered to sheep during experimental studies (Swan et al. 1995).

In the current study, the epoxyscillirosidine concentrations were only determined in the leaves and not in other aerial parts such as the inflorescence, or in the corms. It is highly probable that the epoxyscillirosidine concentrations in yellow tulp may vary during a growing season. Differences in the concentrations of toxic principles in various plant parts and during specific growth stages have been reported for a number of poisonous plants in South Africa such as Fadogia homblei and Lantana camara (Kellerman et al. 2005).

Soil type probably also influences toxicity of yellow tulp. Steyn (1934) reported that another bufadienolide-containing plant, Cotyledon orbiculata, which grows on sandy soils, is more toxic than plants growing on black clay soils. Grosskopf (1964) relayed the opinions of farmers who reported that Geigeria ornativa growing in limestone-rich areas is more toxic.

Many of the earlier research investigations involving GIS and toxicology have mainly dealt with pesticide use and their environmental implications, especially to ground water and/or stream water quality (Corwin, Werle \& Rhoades 1988; Howell, Gelinas \& Slaats 1988; Davis \& Flores 1992; Heidtke \& Auer 1993). Numerous scientific reports also exist where GIS have been used to analyse heavy metal pollution in the environment (Herpin, Berlekamp \& Markert 1996; Markert, Herpin \& Berlekamp 1996; Frangi \& Richard 1997; 
TABLE 2: Median epoxyscillirosidine concentrations in plants and median soil parameter values, to the north-east and south-west of a diagonal divisional line drawn between $-26^{\circ} \mathrm{N}, 24^{\circ} \mathrm{E}$ and $-30^{\circ} \mathrm{N}, 29^{\circ} \mathrm{E}$.

\begin{tabular}{|c|c|c|c|c|c|}
\hline Parameter & Element symbol & $\mathrm{NE}$ & sw & Test & $p$-value \\
\hline Epoxyscillirosidine $(\mu \mathrm{g} / \mathrm{g})$ & - & 54 & 5 & Rank sum test & $<0.001 *$ \\
\hline Iron ( $\mu \mathrm{g} / \mathrm{g})$ & $\mathrm{Fe}$ & 260.03000 & 50.03000 & Rank sum test & $<0.001^{*}$ \\
\hline Aluminium $(\mu \mathrm{g} / \mathrm{g}$ ) & $\mathrm{Al}$ & 70.93000 & 45.63000 & Rank sum test & 0.142 \\
\hline Antimony $(\mu \mathrm{g} / \mathrm{g}$ ) & $\mathrm{Sb}$ & 0.00090 & 0.00093 & Rank sum test & 0.815 \\
\hline Arsenic $(\mu \mathrm{g} / \mathrm{g})$ & As & 0.09525 & 0.07290 & $t$-test $\dagger$ & 0.055 \\
\hline Barium $(\mu \mathrm{g} / \mathrm{g})$ & $\mathrm{Ba}$ & 1.92690 & 2.00000 & $t$-test $\dagger$ & 0.804 \\
\hline Beryllium ( $\mu \mathrm{g} / \mathrm{g}$ ) & $\mathrm{Be}$ & 0.00162 & 0.00000 & $t$-test $\dagger$ & 0.989 \\
\hline Bismuth ( $\mu \mathrm{g} / \mathrm{g}$ ) & $\mathrm{Bi}$ & 0.00600 & 0.00177 & Rank sum test & $<0.001 *$ \\
\hline Boron $(\mu \mathrm{g} / \mathrm{g})$ & B & 0.18700 & 0.29300 & Rank sum test & 0.057 \\
\hline Bromide ( $\mu \mathrm{g} / \mathrm{g}$ ) & $\mathrm{Br}$ & 0.34000 & 0.25200 & Rank sum test & $0.038^{*}$ \\
\hline Cadmium $(\mu \mathrm{g} / \mathrm{g}$ ) & $\mathrm{Cd}$ & 0.03600 & 0.01500 & Rank sum test & $0.009 *$ \\
\hline Calcium ( $\mu \mathrm{g} / \mathrm{g}$ ) & $\mathrm{Ca}$ & 543.55000 & 743.54000 & Rank sum test & 0.463 \\
\hline Cesium ( $\mu \mathrm{g} / \mathrm{g}$ ) & Cs & 0.00300 & 0.00177 & Rank sum test & 0.095 \\
\hline Chromium ( $\mu \mathrm{g} / \mathrm{g}$ ) & $\mathrm{Cr}$ & 0.04000 & 0.02400 & Rank sum test & $0.001^{*}$ \\
\hline Copper ( $\mu \mathrm{g} / \mathrm{g})$ & $\mathrm{Cu}$ & 3.01200 & 1.91400 & Rank sum test & 0.053 \\
\hline lodine $(\mu \mathrm{g} / \mathrm{g})$ & I & 0.02799 & 0.03600 & $t$-test $\dagger$ & 0.151 \\
\hline Lanthanum ( $\mu \mathrm{g} / \mathrm{g}$ ) & La & 3.77700 & 3.44000 & $t$-test $\dagger$ & 0.127 \\
\hline Lead $(\mu \mathrm{g} / \mathrm{g})$ & $\mathrm{Pb}$ & 3.98400 & 1.48700 & $t$-test $\dagger$ & 0.090 \\
\hline Lithium ( $\mu \mathrm{g} / \mathrm{g}$ ) & $\mathrm{Li}$ & 0.02100 & 0.02000 & $t$-test $\dagger$ & 0.579 \\
\hline Magnesium ( $\mu \mathrm{g} / \mathrm{g}$ ) & $\mathrm{Mg}$ & 200.93000 & 315.23000 & Rank sum test & 0.548 \\
\hline Manganese ( $\mu \mathrm{g} / \mathrm{g}$ ) & $\mathrm{Mn}$ & 146.19000 & 79.29000 & Rank sum test & 0.109 \\
\hline Molybdenum $(\mu \mathrm{g} / \mathrm{g})$ & Mo & 0.019000 & 0.038000 & Rank sum test & 0.385 \\
\hline Nickel ( $\mu \mathrm{g} / \mathrm{g})$ & $\mathrm{Ni}$ & 1.92600 & 2.16400 & Rank sum test & 0.423 \\
\hline Phosphate ( $\mu \mathrm{g} / \mathrm{g}$ ) & $\mathrm{PO}^{4}$ & 8.57000 & 6.03000 & Rank sum test & 0.789 \\
\hline Potassium ( $\mu \mathrm{g} / \mathrm{g}$ ) & K & 206.86000 & 208.03000 & $t$-test $\dagger$ & 0.488 \\
\hline Rubidium ( $\mu \mathrm{g} / \mathrm{g}$ ) & $\mathrm{Rb}$ & 0.32190 & 0.11000 & $t$-test & $<0.001 *$ \\
\hline Selenium ( $\mu \mathrm{g} / \mathrm{g}$ ) & Se & 0.20943 & 0.15000 & $t$-test $\dagger$ & 0.090 \\
\hline Sodium ( $\mu \mathrm{g} / \mathrm{g}$ ) & $\mathrm{Na}$ & 12.14000 & 11.50000 & Rank sum test & 0.947 \\
\hline Thallium ( $\mu \mathrm{g} / \mathrm{g}$ ) & $\mathrm{Tl}$ & 0.00273 & 0.00147 & Rank sum test & $0.023^{*}$ \\
\hline $\operatorname{Tin}(\mu \mathrm{g} / \mathrm{g})$ & Sn & 0.02000 & 0.01800 & Rank sum test & 0.300 \\
\hline Titanium $(\mu \mathrm{g} / \mathrm{g})$ & $\mathrm{Ti}$ & 1.40300 & 0.45200 & Rank sum test & $0.038 *$ \\
\hline Tungsten $(\mu \mathrm{g} / \mathrm{g}$ ) & w & 0.00400 & 0.00440 & $t$-test $\dagger$ & 0.535 \\
\hline Uranium ( $\mu \mathrm{g} / \mathrm{g}$ ) & U & 0.00108 & 0.00100 & Rank sum test & 0.616 \\
\hline Vanadium ( $\mu \mathrm{g} / \mathrm{g}$ ) & V & 0.93900 & 0.84600 & Rank sum test & 0.738 \\
\hline Zinc ( $\mu \mathrm{g} / \mathrm{g})$ & $\mathrm{Zn}$ & 4.14600 & 0.89000 & Rank sum test & $0.011^{*}$ \\
\hline $\mathrm{pH}$ & - & 6.08 & 7.86 & $t$-test & $<0.001 *$ \\
\hline Resistance $(\Omega)$ & - & 770 & 1100 & Rank sum test & 0.548 \\
\hline
\end{tabular}

$\mathrm{NE}$, north-east; SW, south-west.

$*$, The difference between groups is statistically significant.

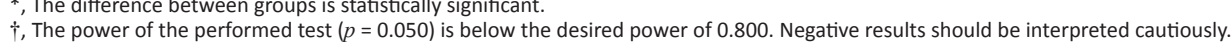

Mielke, Gonzales \& Smith 2000; Facchinelli, Sacchi \& Mallen 2001; Pesch \& Schroeder 2006). Most or all of these studies have centered on risks to human health; nevertheless, they demonstrate the potential of spatial analysis or geoprocessing tools, which are components that are central to a GIS in various toxicological problem-solving scenarios.

Despite the popularity of GIS amongst many medical and environmental toxicologists, there are relatively few veterinary toxicological studies that have used GIS for problem solving thus far. Durr \& Gatrell (2004) wrote extensively about spatial analysis in veterinary science in general, wherein a majority of their topics discussed epidemiological modelling and management of wildlife diseases. Kistemann et al. (2004) studied spatial and temporal distribution of verotoxin-producing Escherichia coli amongst humans and cattle in Sweden. They compared spatial patterns of the distribution of human infections with spatial patterns of occurrence in cattle using GIS. Whilst it is true that the use of GIS is limited to situations that are spatial in nature, it is also a fact that the immense potential of GIS to solve regional and local veterinary toxicological issues is underutilised at present.

The Moran's index indicates a degree of spatial autocorrelation in the data. Although the power of the analysis is not at a level needed for a reliable result, a degree of autocorrelation in this case may support a conclusion that local effects influence toxin levels, which causes plants that grow close together to have more similar toxin concentrations compared to plants growing in more distant locations. This conclusion is also supported by the regional differences between the NE and SW. One of the advantages of visually evaluating data in a spatial context is that it enables the qualitative detection 
of data patterns, which can then form the basis for forming testable hypotheses. The elliptical distribution pattern of the sample locations along the NE to SW axis allows for evaluation along that axis (Figure 1). Although several statistically significant associations between soil parameters and plant toxin concentration were found (Table 2), inferences cannot be made regarding the causal relationship of these associations. However, these results do suggest that further experiments are needed to investigate the potential influence of soil nutrients and soil $\mathrm{pH}$ on toxin production. Due to the distribution pattern of the sample sites, the presence or absence of toxin concentration differences along other distribution axes could not be supported or disproved.

Potential factors that could influence toxin concentrations, but were not investigated in the current study include: regional climatic differences; genetic differences between populations; and local stressors such as variations in insect or other herbivore pressure, pathogens and intra- and interspecific competition. The variation of epoxyscillirosidine concentrations within populations over time also needs to be investigated, including variations in relation to plant growth stages. These data and an increased understanding of the factors that determine poisoning risk will allow an assessment of change in risk that might be expected when environmental changes occur, such as climate change and/ or land use change. The most important environmental parameters that determine epoxyscillirosidine poisoning can then be identified and broader geographic areas can be delineated in a GIS environment as potential areas of yellow tulp poisoning.

\section{Acknowledgements}

The authors would like to extend their gratitude to the veterinarians, students and farmers who collected and submitted plant material and soil samples. We would also like to thank Mrs Nina van Vliet, ARC-Institute for Soil, Climate and Water, Pretoria for the soil analysis and Dr Magda Rösemann at the Laboratory of The National Horse Racing Authority, Johannesburg for the LC-MS analysis. This research is based upon work supported financially by the National Research Foundation, South Africa.

\section{Competing interests}

The authors declare that they have no financial or personal relationship(s) that may have inappropriately influenced them in writing this article.

\section{Authors' contributions}

C.J.B. (University of Pretoria) was the principal investigator. H.C. (Agricultural Research Council-Onderstepoort Veterinary Institute), R.A.S. (Agricultural Research CouncilOnderstepoort Veterinary Institute) and L.L. (Agricultural Research Council-Onderstepoort Veterinary Institute) prepared the plant samples and performed the extraction procedures. D.V.D.M. (Kansas State University) was responsible for the GIS analysis. C.J.B., D.V.D.M. and R.A.S. compiled and edited the manuscript.

\section{References}

Botha, C.J., 2003, 'Krimpsiekte, a paretic/paralytic syndrome of small stock in South Africa: Studies on the aetiology of krimpsiekte, the toxicokinetics and dynamic effects of cotyledoside and seasonal fluctuation of cotyledoside concentration in plant material', PhD thesis, The Norwegian School of Veterinary Science.

Corwin, D.L., Werle, J.W. \& Rhoades, J.D., 1988, 'The use of computer-assisted mapping techniques to delineate potential areas of salinity development in soils. 1. A conceptual introduction 2. Field verification of the threshold-mode approach', Hilgardia 56, 1-32.

Davis, R.M. \& Flores, P.I., 1992, 'Identifying potential pollutant point sources in an area of high ground-water consumption', Ground Water Monitoring and Remediation 12, 116-119. http://dx.doi.org/10.1111/j.1745-6592.1992.tb00041.x

Durr, P.A. \& Gatrell, A.C., 2004, GIS and spatial analysis in veterinary science, CABI Publishing, Wallingford. http://dx.doi.org/10.1079/9780851996349.0000

Enslin, P.R., Naudé, T.W., Potgieter, D.J.J. \& Van Wyk, A.J., 1966, ' $1 \alpha$, $2 \alpha$-Epoxyscillirosidine, the main toxic principle of Homeria glauca (Wood and Evans) N.E. Br', Tetrahedron 22, 3213-3220. http://dx.doi.org/10.1016/S00404020(01)82303-6

ESRI, 2008, What is GIS? GIS.com, A Guide to Geographic Information Systems, viewed 04 December 2012, from http://www.gis.com/whatisgis/

Facchinelli, A., Sacchi, E., \& Mallen, L., 2001, 'Multivariate statistical and GIS-based approach to identify heavy metal sources in soils', Environmental Pollution 114 313-324. http://dx.doi.org/10.1016/S0269-7491(00)00243-8

Frangi, J.P. \& Richard, D., 1997, 'Heavy metal soil pollution cartography in northern France', Science of the Total Environment 205, 71-79. http://dx.doi.org/10.1016/ S0048-9697(97)00184-8

Grosskopf, J.F.W., 1964, Our present knowledge of 'Vermeersiekte' (Geigeria poisoning). Technical Communication No. 21. Department of Agricultural Technical Services, Republic of South Africa.

Heidtke, T.M. \& Auer, M.T., 1993, 'Application of a GIS-based nonpoint source nutrient loading model for assessment of land development scenarios and water quality in Owasco Lake, New York', Water Science and Technology 28, 595-604.

Herpin, U., Berlekamp, J. \& Markert, B., 1996, 'The distribution of heavy metals in a transect of the three states the Netherlands, Germany and Poland, determined with the aid of moss monitoring', Science of the Total Environment 187, 185-198. $\mathrm{http}: / / \mathrm{dx}$.doi.org/10.1016/0048-9697(96)05141-8

Howell, G., Gelinas, R. \& Slaats, J., 1988, 'Identification of surface water acidification sources in Nova Scotia Canada', Water Pollution Research Journal of Canada 23, 520-531.

Kellerman, T.S., Coetzer, J.A.W., Naudé, T.W. \& Botha, C.J., 2005, Plant poisonings and mycotoxicoses of livestock in Southern Africa, 2 nd edn., Oxford University Press, Cape Town.

Kellerman, T.S., Naudé, T.W. \& Fourie, N., 1996, 'The distribution, diagnosis and estimated economic impact of plant poisonings and mycotoxicoses in South Africa', Onderstepoort Journal of Veterinary Research 63, 65-90. PMid:8856758

Kistemann, T., Zimmer, S., Vagsholm, I. \& Andersson, Y., 2004, 'GIS-supported investigation of human EHEC and cattle VTEC 0157 infections in Sweden: Geographical distribution, spatial variation and possible risk factors', Epidemiology and Infection 132, 495-505. http://dx.doi.org/10.1017/S0950268803001729, PMid:15188718, PMCid:2870128

Markert, B., Herpin, U. \& Berlekamp, J., 1996, 'A comparison of heavy metal deposition in selected eastern European countries using the moss monitoring method, with special emphasis on the "Black Triangle", Science of the Total Environment 193, 85-100. http://dx.doi.org/10.1016/S0048-9697(96)05333-8

Mielke, H.W., Gonzales, C.R. \& Smith, M.K., 2000, 'Quantities and associations of lead zinc, cadmium, manganese, chromium, nickel, vanadium, and copper in fresh Mississippi delta alluvium and New Orleans alluvial soils', Science of the Total Environment 246, 249-259. http://dx.doi.org/10.1016/S0048-9697(99)00462-3

Pesch, R. \& Schroeder, W., 2006, 'Spatiotemporal variability of metal accumulation in mosses. Analysis of measurement data and metadata by statistics and GIS', Nova Hedwigia 82, 447-466. http://dx.doi.org/10.1127/0029-5035/2006/0082-0447

Schultz, R.A., Kellerman, T.S. \& Van den Berg, H., 2005, 'The role of fluorescence polarization immuno-assay in the diagnosis of plant-induced cardiac glycoside poisoning of livestock in South Africa', Onderstepoort Journal of Veterinary Research 72, 189-201. http://dx.doi.org/10.4102/ojvr.v72i3.195 PMid:16300187

Snyman, L.D., Kellerman, T.S., Schultz, R.A., Joubert, J.P.J., Basson, K.M. \& Labuschagne, L., 2004, 'Conditioned feed aversion as a means of preventing intake of yellowtulp (Homeria pallida) by livestock', in T. Acamovic, C.S. Stewart \& T.W. Pennycott (eds.), Poisonous plants and related toxins: 6th International Symposium on Poisonous Plants proceedings, Glasgow, Scotland, 2001, pp. 531-539, CAB Publishing, Wallingford.

Snyman, L.D., Schultz, R.A. \& Van den Berg, H., 2011, 'Variability of yellow tulp (Moraea pallida Bak.) toxicity', Journal of the South African Veterinary Association 82(2), 131-132. http://dx.doi.org/10.4102/jsava.v82i2.48, PMid:22135929

Steyn, D.G., 1934, The toxicology of plants in South Africa. Central News Agency Ltd, South Africa.

Steyn, P.S. \& Van Heerden, F.R., 1998, 'Bufadienolides of plant and animal origin', Natural Product Reports 15(4), 397-398. http://dx.doi.org/10.1039/a815397y, PMid:9736996

Swan, G.E., Schultz, R.A., Kellerman, T.S., Mülders, M.S.G., Maartens, B.P. \& Van der Walt, J.J., 1995, 'In vivo effects of a novel calcium antagonist (R56865) against induced epoxyscillirosidin and tulp poisoning in sheep', Onderstepoort Journal of Veterinary Research 62, 163-166. PMid:8628568 